\title{
Terror and New Media
}

\author{
Şahin, Z. B. ${ }^{1}$ \\ 'Zeynep Burcu ŞAHIN, Istanbul Aydin University, (Turkey) \\ e-mail: zbvardal@hotmail.com.tr
}

\begin{abstract}
Terror is not an ordinary act of violance. The ultimate goal of terrorists is to become popular and to announce their ideology by fueling terror, panic and fear. At this point, the terror's dependency on and need for media is clear. As for media, because of its public accountability, it is responsible for transmitting news, information and thoughts. This symbiotic relationship between media and terrorism has been debated since the occurrence of mass media; several solutions have been proposed regarding how and at what rate the terror news should be published in media. Today, the necessity for media's sensitivity to the journalism of terror and its responsibility has been increased. Hence, the information gap opened in traditional media is loaded most of the time with news, information and content shared by terrorist organizations' media channels and terrorists or sympathizers, in an uncontrolled area -new media-. Along with the relationship between terror and media, with the structure of feeding each other, it is observed that the terrorist organizations take advantage of new media and modern communication technologies professionally. Herein, journalism of terror has to be carried out in a professional way by abstaining from publication bans and modern concept of terrorism in question has to be head off via new media with safeguards. At this point, government's efficient use of new media in counter-terrorism and user education of critical new media literacy is important.
\end{abstract}

Keywords: terror, terrorism, new media, Isid

\section{Introduction}

The relationship between terror and media has been debated parallel to the developments in mass media. Today, this issue is increasingly growing up with the acceleration of technological developments and the progress of new media. Thus, it is not terror's use of media at issue, it is creating its own media, disseminating their speeches and actions to large masses by using technology and new media. Internet's unlimited free structure makes fight with this problem by imposing legal restrictions difficult. At this point, it doesn't seem possible for the defended responsible media view in the media fight against terrorism to be successful without being supported by concious users.

Terror news ignored by media organs or prevented by governments via publication bans is against the public rights of reaching news, information and thoughts. At this point, the issue to be discussed is the way the terrorist incidents are to be made news. Hence, use of titles and images creating panic, presenting the incident with lifted effectiveness by dramatizing, sharing scene, dead and injured photos, sharing information effecting the investigation or judgment process, giving permission to the terrorists' propaganda by giving place to the speeches of terrorist organisations immediately after the incident will serve for the goals of terror.

Terror is a fact that threatens social security. In this fight too, it is essential for all the society's constitutions to work together. Specially, due to the involuntary relationship with terror, the role of media is big in this sense. Fight against terror increasing its effectiveness with the help of mass media will be again possible in the optimum way by means of mass media.

This work aims to consider the relationship between new media and terror and to offer suggestions for the efficient use of new media on the counter-terrorism. In this work, literature search method is used. 


\section{Terror and Terrorism}

Terrorism, is derived from the word "terror" meant " extreme fear and anxiety, terror felt in the face of an unknown and unforeseen threat" in Latin. (Öktem, 133) Thus, in TDK too, terror is defined by "discourage". Although in respect of the content terroris as old as the human history, as a political and legal term terrorism is started to be used to express the systematic violence policy carried out by Jakoben regime in the convention era 1793 followed by 1789 French Revolution. Herein, it is possible to mention that the starting point of the concept is "state terror". As for today, terror is not just limited to state terror; it brings performed acts of violence within the frame of political and/or religious ideologies to mind.

Bilir defines terror as " the use/the threat to use of violence or power by the people unauthorized to use violence with a political goal, against the civilian population, the overuse by the people authorized to use violence or against the uncivilised, the use that crosses the limits arising from international law" (2009:40).

In the 12.04.1991 dated and 3713 numbered Anti-Terror Law article 1 terror; " by using force and violence; with one of the methods of pressure, threat, intimidation, suppression or menace, in an attempt to change the qualities, political, legal, social, secular, economical layout of Republic mentioned in fundamental law, to break the indivisible integrity of the state with its country and nation, to endanger the existence of the Turkish State and Republic, to debilitate or to demolish or to capture the State authority, to annihilate the fundamental rights and liberties, to break the State's internal and external security, public order or public health, all kinds of attempted criminal acts by organization member or members". This considerably detailed and comprehensive definition shows that while defining terror, each society and state considers its own sensitivities. At this point, as for the representation of terror, the occurence of various differences in media seems inevitable. Indeed, making terror news varies by the culture and journalism practices of the country in question (Melek, Toker, 2016:180) and in this sense obliges each society to develop its own practices.

Although today terror and terrorism are substituted for each other, the meanings of the two words are different. Hence, while terror is an action, terrorism is a thought system that defends and transfers this terror action systematically. (Kazan, 2016:112) While terror can be defined as the short term act of violence without a political goal, terrorism is a systematic thought system and carries major qualities.

Alex P. Schmid determined 140 different definitions of terror. Among these, there are 22 common qualities and 20 common goals or functions. The most frequently mentioned five items are: (Ergil, 1992:140)

1. The use of violence or force

2. Pursuing a political goal

3. Spreading dread and fear

4. Threat

5. Psychological effect excited on the society and expected common reaction from third parties (except the terrorists and the victims).

Gezgin asserting that world has been stepped into a terror zone in recent years, refering to September 11, London and Madrid attacks, argues that by targeting massive deaths terror has been detracted to a large extent from its ideological grounding based on "not killing innocent people" until then. (2006:11) In the new terror era the ideological and political identity of murdered people has been sort of trivialised; they have been turned into nameless mediums in the message intended to be given. Nowadays, innocent crowds-oriented terrorist actions independent of the message terror organisation wanted to give superseded individual-oriented terrorist actions. At this point the aim is to reinforce the message wanted to be given with the death of a large number of people and to generate threat by creating a general air of fear.

In complience with the fundamental principles of law, determination of crime and punishment is primarily possible by defining the action assumed to constitute a crime. However, although the concepts of terror and terrorism are tried to be embodied by being defined in the international legal texts, there is not a common definition arrived at a consensus. It is possible to explain this situation by various factors. First of all, the concept of terror gaining different meanings in political, social and 
international dimensions causes different definitions to be required for each said context. "The complicated and subjective feature of the fact terror, owning political, sociological, economical, legal, philosophical, ethical and international dimensions, makes it impossible to settle on a common definition." (Bıçak, 2001:115) This indefinableness issue precludes legal solutions and international collaboration, terror poses a threat as an increasingly growing issue over all communities including developed Western countries. In addition to this, the indefinableness of terror again smacks of states utilizing said concept within the frame of their own national interests and keeping away from international cooperation.

Thusly, the concept of terror in sociological meaning and political aspect don't express the same meaning. On the other hand, as each society has its own features, detection and management of danger and fear are implemented differently from each other.

In addition to this; today the biggest obstacle in front of the application of legal sanctions against terrorism becoming a global issue, is states' adverse interests. Each nation dwells on a definition within the frame of its own national interests and does not prefer to come to agreement. Specially, even though after the September 11, 2001 attacks works on this issue gained an intensity, as long as the double standart states applied on each other on terror problem continues, it seems impossible for terror problem to reach a solution; on the contrary, terror taking advantage of the power of technology and communication, confronts us as an even bigger problem.

Today another reason of unsolvableness against terror is terror organisations' outer connections. Inside the national borders, terror problem being tried to be worked out with legal, military or political methods, most of the time has been fed, even organised openly or underhand by the other states with common national interests. In fact, terror is an international problem executed against humanity. The created incomprehensibility on this issue and the acceptence of organisations accepted as terrorist by some states, as minority groups seeking their rights with the description of "resister" or "freedom fighter" by other states, is the biggest obstacle in front of the problem in question.

Arguing terrorist attack differs from arguing political ideological and thoughts funding terrorist attack. "Goals presented by terrorists or reasons for their conducts could be substantially or partly true, even right (otherwise at a certain level they wouldn't be supported). However, terrorist action itself can never be right." (Ergil,1992:140). In addition to this, revealing representation of anomalous voices in media and society as a necessity of a democratic environment seems to decimate incomprehensibility of the terror concept. Nevertheless, the sensitivity of terror concept, different interpretations of social memory and history make this difficult today from the point of our society; free thought and discussion platform is precluded. Thoughts to be tried to be announced with terror actions, totally lose their legitimacy within this period; and also confront us as news discussed and damned in media.

\section{Terror-Media Relationship}

Media and terror relationship, in the past century, has been argued parallel to the developments emerging from mass media. Thusly, soon after the start of World War I, French General Staff agreed upon the issue that any journalist would not go into the war zone without being accompanied. General Staff had simply seen the press as a source of information for the enemy. It is again remembered that in that period in the 1870, French-Prussia War, journalists caused to lose the war by publishing information on the status of military tactics and troops. (Matusitz, 2013:63) Similarly, during the America's Vietnam War, it is possible to attribute global loss of reputation to television broadcasting in that period. (Matusitz, 2013:63)

There are generally accepted two different opinions on terror and media relationship; "according to the first view, media has duties toward society, state, international system and occupation policies and within this scope it is required not to give place to terror news. As for another view, due to the same responsibilities and in addition to these within the scope of informing public opinion about what's going on, media should give place to terror identically and clearly." (Pazarbaşı, Koç, 2009:163) In this work, none of the views are adopted, it is focused at the point that media is a medium. Media is a medium erecting ideological discourse all over again. As for the relationship with terror comes into question, it is seen that media is a medium used by terror on the way to reach its goals. Media has the right of freedom of expression and press, and public has the right to keep informed. These two freedom serving voluntarily or involuntarily for the terror organisation's objectives considerably lose legitimacy at the moment of endangering public security. 
Theoretically, ensuring public security is not included among the duties of media. If we check from a legal aspect ensuring social peace or ensuring public security can not be counted as the duties of media. Yet, any situation threatening public security has been accepted inside the borders of freedom of expression by all democratic constitutions. At this point, when fight against terrorism is in question, media by taking public security forefront should act controlled. Fight against terrorism is a total war touching whole society,both media and new media can not be excluded from this fight.

Liberal pluralist view's thought that media reflects the lived truth, today has given place to the view of political economy's approach that media erects the truth all over again within the frame of its own political economy approach. No doubt at this situation media's changing and complicating organizational structure and today's global conditions have also been influential. Media is an institution in business in the free market conditions and serving semipublic. The content of service it provides composes of "news". It is an indisputable fact that terrorist actions are newsworthy from the point of media. Hence, media has the aim of profit maximization and by calling public attention, presents news content that will increase sales. In a research conducted, $77.1 \%$ of the subjects told that on the television and newspapers news that excite their attention most was terror news. (Avşar, 2009:64)

Terror is fed with fear, panic and curiosity. Notwithstanding that public interest on these news media giving is contradictive, "in media generally interest for crime news is directly associated with circulation and rating needs and expectations." (Avşar, 2009:66) All the bloody images and details of Munevver Karabulut murder occupying agenda of media for weeks, occured in 2012 is such as to support this opinion. In the meantime, finally Haberturk paper increasing its circulation by giving the photo of bloody saw in the first page and its Chief Editor Fatih Altaylı had come under criticism. (Mehveş Evin, Bazıları Utanma Nedir Bilmiyor, 25.09.2012, http://www.medyatava.com/haber/mehvesevin-bazilari-utanma-nedir-bilmiyor_40042, E.T. 07.03.2017)

Society's interest and curiosity on violence news and images confronts us as a fact that should be analyzed sociologically and pathologically. In fact, Crelinsten suggests that terrorism ,in media presentation for a very small part of the society, presents political action models serving as provocative samples, awakening the violence fantasies at the state of sleep. (Avşar, 2009:71) At this point, the purpose for media giving terror news gains importance. Terror news are not fictional images or stories. They consist of actual true events and have sociological, ideological and political dimensions. The duty of media is to give news within the frame of legislation and to ensure news to be considered with these dimensions. As for terrorist action considered with dramatic aspects serves for the goals of terrorist organisations, so detracts public from the principal points supposed to be emphasized; feeds the feelings of fear, pain, hatred and panic.

If we look at the relationship between traditional media and terror, it is seen that the two said concepts are feeding each other. However, in this regard it shouldn't be neglected that media is a medium. Specially, in today's capitalist market conditions, media has a structure that disseminates and popularizes the dominant discourse in accordance with the interests of political and economical power.

Terror's chief goal can be summarized as reaching different political goals by creating fear and panic. In other words, the chief goal of terrorist actions is to create fear. In the meantime as to the murder of people, it is in the position of a medium to reach this goal. "Terrorism's power is not from the loss of lives or property that it caused. In this sense, it is not the impact of terror that makes it dangerous, it is the reaction that it generates. The influence is much bigger than the action itself. The effect of terror is not measured by the destruction it caused, but by the psychological reaction that it awakened. The reactions of communities cannot be indicated by statistical values. While terrorists give shock to public opinion with ostentatious and exciting actions, they make the official authorities to mobilize against themselves. They legislate their claims." (Ergil, 1992:142) Traditional media's most of the time involuntarily occured support for terrorist actions begins at this point. Media with the duty of conveying news information and thoughts to the masses, unconsciously or consciously serves for the goals of terror by giving place to terror news in such a manner that creates top effect for the sake of gaining rating,; on the one hand serves for the occurence of the air of fear and dread in the society, on the other hand makes propaganda by informing people owning similar opinions with terror groups.

"Since terrorist attacks has many resources towards these multi-directional approach should be shown. Firstly, criminology should be applied; because terrorism is a crime. Secondly, strategy should be applied; because terrorism is a war. Finally, a political approach should be adopted; because terrorism is at the same time an ideology."(Fidan, 2006:65) 
The objectives of terror are to become popular, to attract attention and to influence the decision mechanisms by frightening the public. Accordingly, media confronts us as the most effective medium of terror. On the other hand, when the fact that the objective of media is to increase its sales by means of attracting the public's attention is taken into consideration, it is seen that media and terror are feeding each other.

It is seen that in western countries special criteria are developed on terrorism actions occured in their own countries to be reported as news. Without the application for the publication bans, news are analyzed within the frame of the said criteria; public welfare, national interests, apprehension of rating and thereby kept before public's expectations.

England Sample. As BBC (British Broadcasting Corporation)'s publication principles on terror are checked, these are seen; it should be safe from the image of corpse should. No close-up shots of dead and injured should be taken. Terror news should be given but carefully. Media should not be an instrument of propaganda and promotion of terror.

"The rules determined by English public broadcaster BBC are the following:

1.The dead should be handled deferentially, should not be issued unless there is forced causes.

2. Close-up shots should be avoided.

3. Bloody results should not be dwelled on much.

4. Human life and its suffer should be valued.

5. Terror news should be given responsibly; it should not be forgotten that rumors on terrorism are killer.

6. Official secrets law should be considered on issues regarding national security.

7. Interview with terrorists should be made if there's public interest, before it's made it should be asked from broadcasting policy controller.

8. BBC should not be an instrument to terrorist shows with the aim of propaganda and promotion,

9. The language terrorists using should not be used as it is pressman's." (Fendoğlu, http://www.sde.org.tr/tr/authordetail/teror-ve-medya/1099, E.T. 03.01.17)

"Media in compliance with its duty will want to "include" terror news, likewise audience will want to "know", and authority will "oppose" against this but the important thing is to find the "balance", to ensure "proportionality". In Turkey and in the world media, generally, is in the structure resistent to authority's regulations. As it is known that media is a sector that is being shaped by individual's right of obtainment of information, sociological tendencies, audience's expectation and socio-economic pressure." (Fendoğlu, http://www.sde.org.tr/tr/authordetail/teror-ve-medya/1099, 03.01.17 )

"... it is that as terrorism's direct reason is terrorists, indirect reason is the countries and regimes supporting terrorism and accepting it with tolerance. Because of this, mass media has to be made less useful for terrorists." (Özgen, http://www.siyasaliletisim.org/dr-bahadr-kaleaas/prof-drmurat-oezgen/456-fade-oezguerlueue-balamnda-medya-ve-teroer-olgusu.html, 03.01.2017)

The factor isolating terror from other violent acts is the fact that its primary objective is to have anxiety for conveying message rather than murdering people.No pathological propensity for violence lie at the heart of terrorist actions. In other words, terrorism is the expression of rationality and rational strategic preference, not a psychological disorder, nor tendency to violence. However, this situation does not mean that terrorist actions are moral and legitimate. (Küçükcan, 2010:37)

In case of messages not delivered/ not able to be delivered, terrorist organisation's act of violence will not reach its goal. Terrorist organisation reinforces the message that it wants to give not only by murdering, but also by turning death into a show. At this point, society's interest and addiction 
to violence images coalesces with media's anxiety for rating and forms a basis for the consequences to the detriment of media in terms of both social, economic and political aspects.

At this point, the meanings of the concepts of terror, terrorist and terrorism have gained importance. The parties of terror actions are not composed of the person and people who carried out act of violence or victims. The primary objective of terrorist action, in other words its true victim is the society itself. Terrorist organisation inevitably uses media as a medium while reaching its final goal. At this point, it can be mentioned that there is a symbiotic relationship between media and terrorist organisation. (Kazan, 2016:24) As for the society, in the role of main victim with the addiction to violence images, it is determinative on the manner toward the issue of media serving these images and reporting news of terrorist actions.

Media, today involuntarily became terror's one of the most effective weapon. Both media itself carrying the duty and responsibility of anunciation and enlightening public opinion and developments occuring in communication technologies create a situation for the benefit of terror and terrorists. Barriers in front of the precautions to be taken in this direction can be given as;

1. Different descriptions of the concept related to terror and terrorism by both national and international different media institutions

2. The developments on mass media and internet transmitting the said contents to large masses fast and efficiently

3. Masses unconsciously consuming/popularizing images and contents gradually started to be produced one each as a production by terrorist organisations

Terror's chief goal is to draw public's attention by taking place in media; to reach their goal by prompting the feelings of dread, fear and curiosity. Intentionally or unintentionally, media's serving for this goal is foremost against the social responsibility principle. The duty of media is to serve towards the enlightenment for the public welfare, and closed to providing benefit for the terrorist organisations. (Gezgin, 2006:14)

Accordingly, media's responsibilities for the solution of the problem can be subsumed under two titles; "First, while reporting the news of various attacks carried out by terrorist movement to democracies, Second; uniting democracies against this instability threat, media plays an important role." (Fidan, 2006:65)

War on terrorism is an action not just under media's responsibility. This problem whose effects can be seen in many fields, besides political, military, sociological solutions and analysis, it is necessary to raise awareness on media and through media whole society. A country such as Turkey fighting against terror for years, in this area much more work has to be done and fight methods should be kept alive. Media is a medium and frequently carries and reflects its society's dominant ideology. By amplifying violent acts performed in the hands of terrorist organisations media taking on the duty to lift its effectiveness, will similarly take an effective task in the war on terror.

Many researches conducted reveals that the most read news are terror news. (Avşar, 2009:63) Terror news having this much importance at society confronts us as an issue that is to be analyzed from sociological aspect. In this regard, terrorist actions except creating fear and panic by posing security threat and feeling necessity for news and information appeasing this panic, individuals' interest and addiction to violence images has been drawing the attention.

"In Turkey and in the world terror wants to use especially screens to reach its goal. Actually terror is an advertisement and propaganda method; it is an advertisement style for the districts not reaching their goal with democratic method to prove their own power. Namely, an action that is done once, is shown on the screen again and again and so the action seems to be done thousands of times instead of one action." (http://www.sde.org.tr/tr/authordetail/teror-ve-medya/1099 E.T. 26.06.2017)

If we look at the terror actions occured in 2016, it is seen that right after almost all action, a broadcast ban had been imposed. These broadcast bans prevented public from receiving information; with the atmosphere of uncertainty it had created increased the fear and panic environment, which is the chief goal of terrorist actions.

The main problem is not whether public is informed on the issue of terrorist actions or not, it is in what way this informing can be carried out before positioning as a medium of terrorist organisations. 
This issue having importance at both national and the international level can not be carried out within the frame of personal ethical values by people who are not experted on the issue. At this point, it seems to be mandatory for professional members of the profession working on the media's terror news side to be trained under a special education. In Turkey, fighting against terror for the last 35 years, although there are academic studies, no concrete study have been conducted on this case.

Censor and broadcast bans increase the interest for terror news; provide a basis for uncontrolled fast propagation of violence and propaganda images. These images going quite out of the borders of annunciation and presenting one each violence/power show serves for the goal of terror. Public being informed in time, in a true and unbiased way will preclude largely the said images becoming widespread.

Today communication technologies have been developed in an unpreventable way; cuttingedge technology is also being used populously by terrorist organisations. Broadcast bans by triggering feelings of wonder and fear, creates a mass open to speculation, misinformation and propaganda. As it is considered that terror is a national security problem, it is clear that these two tasks should not be left to personal ethical approaches of members of journalism profession. On the other hand, media coupled with producing semipublic service, is an institution acting with the goal of profit maximization within the capitalist system. It is impossible to think that during content selection and service acting in accordance with consumer's expectation, it will not aim to increase its sales or the number of watchers/listeners.

In journalism, there are fields that necessitate specialization such as legal reporter, magazine journalism, sports journalism. As for the terror news, among these, they are the news that necessitate highest sensitivity and specialization. This specialization has importance inasmuch as disallowing "ironic" growth.

On the issue of terror journalism the problems encountered in Turkey and in the world can be summarized as follows;

Not being able to build consensus in the point of defining terror and terrorist groups

The interest of media organisations and public for sensational journalism, violence and violence images.

Not ensuring journalism towards knowledge and democratic discussion environment

In media organisations, not employing experted job professionals on this issue

Not giving enough education on terror journalism, preparing news requiring high sensitivity as terror news together with other news contents under rating curiosity.

In the world becoming global day by day with mass media not adopting international consensus and common understanding

Perceiving legal restrictions as violation of freedom of press

Using sensitivity for terror and national awareness as a legitimate ground for regulations preventing freedom and public's right to receive news

\section{The Concept of New Media and Social Media}

With a very general definition new media is all of the methods ensuring entertainment and information to reach consumer and everchanging. In this sense, coupled with moving towards a goal in continuous progression, by the moment it can be said that new media is composed of concepts against traditional communication methods such as internet, smart phones, digital televisions. (Hollingsworth, 2005:37)

Manovich, in his book "New World" analyzes properties separating new media from traditional media under five titles. These are; numerical representation, modularity, automation, variability and transformation. (Manovich, 2002 ) 
Numerical representation: Either it is created on the computer starting from zero, or transformed from analog media resources, all new media contents are composed of digital codes, in other words numerical representations. This situation has two consequences; first, new media objects can be described mathematically. For example, it is possible to show an image or a shape with mathematical functions. Second, new media objects are convenient for algorithmic manipulation. With appropriate algorithmic applications, you can remove voice from an image, you can adjust contrast. Briefly stated, media has become programmable.

Modularity: This policy can be defined as new media's fractal structure. The same way a fractal has the same structure for different measures, new media objects has a similar modular structure. Media structures consisting of images, voices, shapes and behaviours represented as discrete samples (pixel, polygons, voxels). Even though these objects are mounted in a larger scaled object, they can keep holding their discrete identities.

Automation: The properties of new media's numerical representation and new media object's modularity, allow many operations such as creating media, manipulation and access to happen automatically.

Variability: Another consequence of numerical sample and modularity is variability. New media object is not stable; different and potentially infinite versions can emerge.

Transformation: As the fifth and the last property cultural coding, according to Manovich, constitutes computer based media's the most important consequence. It means the transformation of texts, images and voices to folder structures, lists, records and sequences, by being coded in the computer environment.

"With another definition it can be said that new media technologies are the new methods developed also for old technologies. Among these new methods, there are e-book; facebook, twitter, digitally produced animation and 3D movies. Media revolution occured within the frame of innovations of technology brings its culture. This new culture defined also as a numerical culture mentions changes technologies created on society." (Şişman, 2012:90)

Communication has been continued since the existence of humans. What is changing is the medium people using. Each new developed communication devise; inevitably affect human, society and culture. Especially, last 20 years rapid and fast changes occured in the communication technologies reveals reflections from daily life to political and economic life in all parts of social life. Especially thought for technological aspects, these changes mostly reveals itself as a development, existing technologies are renewed by developing.

Communication underlying the human relationships, each new development in communication technologies leads to the consequence that brings social and cultural changes. At this point, it is inevitable that press being a mass media and journalism activity is the most effected professional activity from these changes. In addition to this, because of press and journalism profession possesing the power to effect masses, it has been criticised before as well; different steps are taken for this power to be controlled and considered from the responsibility aspect.

\section{New Media- Terror Relationship: Isid sample}

With the development of new communication technologies, terror media relationships became more complex. The dependence of terrorist organisations constituting their own media and making the best of modern communication technolojies on traditional media has gradually decreased. It carries the research question of before this problem just media and terror relationship and how often and how terror news should appear on media, to a different dimension. Today it seems impossible, within the frame of legal boundaries, to prevent messages and contents terrorists broadcasting and reaching the large masses. Indeed, developing communication technologies enable any content to reach large masses in an instant, this velocity increases geometrically under the favor of militants organized inside new media. "Along with the new media layout, the amount of information produced in media sector has increased, the dissemination of news has got easy, the speed to reach users has increased, especially with user derived contents, citizen journalism has become popular and so within the journalism, the discrimination of professional/unprofessional has become blurred. (Avşar, 2017:125) 
The ultimate goal of terror is by creating fear, panic and curiosity, to reach its political or ideological goal. It seems impossible to reach this result just by performing the violence action. At this point, developing communication technologies has become the most important tool in the hands of terrorists. Today it seems that terrorist groups aware of this power use mass media in the name of reaching their goals. Tendency to visualized news has also caused the use of violence images for terror actions to be reported as news. In addition to this, terrorist organizations themselves presents violence images via mass media. In fact, these images are prepared professionally with effects and musics and are watched, shared by millions of people.

The message to be given by means of murdering a person is presented by being supported with all the opportinities of communication technologies and the effect of the content has increased. High quality violence videos presented one each as a production, shared on both terrorist organisation's media channels and on social media tools such as twitter, youtube, facebook; and by traditional media institutions having curiosity for rating; and being watched again and again by users ; unconsciously being shared again are the best samples for this situation. In this regard, one side of war on terror happening through mass media reveals the necessity. Indeed, on one side as much as blocking hazardous news, images and contents for the society, in this war carried out through communication tools, media should be expelled from being a tool for terror to reach its goals, it should be made a tool used for the war on terror. Therefore, it has importance to raise awareness of both the society and the media.

To prevent this voice, image and news reaching large masses, incompatible with freedom of speech, gains importance for both political and sociological aspects. Social and political reality witnessed by the individuals influence their personalities. (Küçükcan, 2010: 42) As a sociological institution, both media and new media's effects on the individual's improvement and socialisation should not be ignored. In fact, one of the long-term effects of the use of new media conciously or unconciously in a way that supports terror is to increase the tendency to violence; to awaken interest and sympathy for the terror and terrorist.

Especially for the recent years, terrorist organisations's interest for the mass media has increased, the case proceeded to employing experts on these tools. (https://www.theatlantic.com/international/archive/2014/06/isis-iraq-twitter-social-media-

strategy/372856/, E.T. 23.07.2017) Terrorist groups aware of the effect of violence images on public, have started to conduct special works on this field; to serve media images themselves and even they themselves to serve the world via their communication channels. Especially at the point internet technology reached, it seems that media's sensitivity and expertise for giving terror news is not enough. Media should be kept from being a tool in terror and also should be used as a powerful weapon for the war against terror. Today terrorist actions have been started to be presented as a show with the support of technological developments.

Also, broadcast bans applied in traditional media direct public to new media, terror news that should be given professionally, can be presented unrealistic in company with the violence images. These images and informations shared without attesting play a huge role for the terrorist organisations reaching their goals. At this point, the task falling to traditional media and governments should be to prevent information pollution that might be emerged in new media by giving terror news controlled and professionally.

It is necessary to use new media along with traditional media as an efficient medium on giving terror news and correcting the wrong news. It is clear that legal boundaries and restrictions does not have much effect on new media's free environment. Therefore, the task to be done is to fight with the same tool against the images and news terrorist organisations served as the first news source.

At this point, to raise awareness of public gains importance. There is an important difference between giving terror news and sharing terror images. While one serves for the public's right to get information, the other addresses mostly it's interest for curiosity and even violence images.

Terrorist organisations starting to use internet the first time happened in the end of 90's. (Pellerin, 2015) Isid is not the first terrorist organisation that increases the effect of its actions by using internet. However, today it can be counted as one of the organisations using most efficiently. Although its name started to be on agenda by violence videos, the date of establisment of Isid is 2004. After 
USA's invasion of Iraq on March 21, 2003 morning, it was founded with the name of "Tevhit ve Cihat" by Ebu Musa Zerkavi. It is active in the North regions of Middleeast.

According to Pellerin, the success of Isid's communication strategy depends on five factors; news agencies and news offices, the efficient use of social media, professional videos, the magazine Dabiq and to substitute Western media. (2017:3)

Isid's known news agency is Amaq, however, it has news offices in the regions under its rules. These news agencies both service instantly the messages and images terrorist organisation wants to give and provide the communication web within the organisation. It is known that traditional media institutions having curiosity for rating and being obliged to take their news resources especially after the beheaded murder of the journalist James Follay, USA, in 2002, use and even link to the news and images of the said news institutions.

"New communication technologies enable terrorists to create their own messages directly free from the surveillance of media's gatekeepers, the bindingness of ethical and legal codes, with an unprecedented speed." (Avşar, 2017:127) At this point, it can be seen that censorship and broadcast bans applied to traditional media again serve for the terrorist groups. Traditional media ignoring terror news on purpose or within the frame of legal boundaries, prompts public to follow news, information and images from social media; this situation results in for the good of terrorist organisations.

In Turkey, in 2016, all the year round, there had been 26 terrorist attacks. After each terrorist action happened, broadcast bans are applied. However, these restrictions did not prevent these images from being shared in social media and other media tools, on the contrary, increased the interest and curiosity for the said images. Indeed, legal restrictions lead to information pollution and cause public to be directed towards social media as the only news source and to get wrong information and/ or for the good of terrorist organisation.

In media centered terror, the most effective violence action that has been done, until today is September, 11 Attacks. Attack had broadcasted as newsbreak and live all over the world. In July,2004 September, 11 commission, in their report, included the following expressions; (Weimann, 2015)

"We are facing with a sophisticated, patient, disciplined and fatal enemy. Enemy, by requesting solution for political displeasures, sponsors from Arabic and Muslim world but hostility against us and our values is unlimited.

...terrorists, has taken advantage of rapid improvements in communication technology. The rise of World Wide Web, offered much more simple methods on acquisition of knowledge and command and control of their operations. ...

One another goal of terrorist organisations using social media is to sponsor and to supply participation to the organisation. Brookings Institute in Washington, stated that in 2015 there had been around 70.000 account supporting ISID in Twitter. Isid has the capacity to reach millions of people through social media. According to the data in Google in 2016. February, each month more than 50.000 people are calling for the "Participate Isid" sentence. (Berrada, Boudier, no date:1)

It is seen that Isid adapts easily to the change in present conditions and can make alternative news resources. Indeed, with the shut on their Twitter accounts in September, 2015, organisation started to use the channel property of telegram. (http://www.bbc.com/turkce/haberler-dunya40187203, E.T. 23.09.2017) In addition to this, Isid is not working with one account. Organisation members with the duty of being active in the internet open simultaneously many same accounts; in the case that any of them is closed, continue to make organisation propaganda and provide communication. Isid not distinguishing fight carried out by way of media from war on the field, accepts dead while producing video or digital content as media martyr. (http://www.bbc.com/turkce/haberlerdunya-40187203, E.T. 20.10.2017)

\section{Conclusion and Suggestions}

The goals of terror are to become popular, to draw attention and to influence decision mechanisms by frightening the public. Accordingly, media confronts us as the most efficient tool of 
terror. On the other hand, it is seen that media and terror are feeding each other if the fact that the goal of media is to increase its sales by drawing public's attention is considered.

It is seen that Western countries developed special criteria to report terror news. The news are analyzed within the frame of said criteria without the application of broadcast bans; public welfare, national interests, the worry of rating and thus precedes public's expectations.

In Turkey, there occured 26 terrorist attacks all round year 2016. After each terror action happened, broadcast bans are applied. However, these restrictions did not prevent the images from being shared in social media and other new media tools, on the contrary, increased the interest and curiosity for the said images.

The broadcast bans applied on traditional media, direct public to new media and terror news needed to be given professionally, are presented unrealistic with violence images. These images and information shared without being attested have a huge role in reaching the goals of terrorist organisations. At this point, the task falls in the traditional media and governments is by means of giving terror news controlled and professionally ,to prevent information pollution to be occured in new media.

For reporting terror news and correcting the wrong news, it is necessary that besides traditional media new media should be used as an efficient tool. It is clear that legal restrictions and preventions don't have much effect on new media's free environment. Therefore, it is necessary to fight against the images and news served by terrorist organisations with the same tool as the first news source.

At this point, to raise awareness of public is important. There is an important difference between giving terror news and sharing terror images. While one serves for the public's right to get information, the other addresses mostly the interest for curiosity and even violence images. Sharing and disseminating these images unconsciously serve for the goals of terrorist organisations.

Amble gives the actions to taken for the issue of war on terror in the new media environment; (Avşar, 2017:130)

1. To increase the new media literacy programs for the information community's digital data

2. To show a goal-oriented approach to follow terror groups' media products

3. To transform human intelligence in a way that will fit in the new media environment

In addition to this, the cencor and broadcast bans should be ended; traditional media and government should work together on the terror issue. Government should popularize the anti terror video and images in the social media with a special unit, awareness of public should be raised in this context.

Today war on terror has gained a different aspect and mostly it is done via new media. Government too should develop new techniques on the issue of fight against terror in this new field and should benefit from the opportunities of new media. In this sense, new units should be set up and each action of terrorist organisations on social media should be followed.

Raising awareness of especially teenagers and children exposed to all kinds of violence and terror images through social media and education of critical new media literacy with critical media literacy is necessary.

It is known that Isid via social media gathers militants and organizes visual educations.

\section{References}

[1] Avşar Z (2009) Terörizmle Küresel Mücadele Stratejisi İçinde Medyanın Yeri Ne Olmalı? Terör ve Haber Söylemi. Istanbul: Literatürk

[2] Avşar Z (2017) İnternet Çağında Medya, Terör ve Güvenlik. Ankara: TRT Akademi, Cilt:2 Sayı:3

[3] Berrada, Boudier, The ISIS Twitter Census, Center for Middle East Policy at Brookings

[4] Bıçak V (2001) Avrupa İnsan Hakları Mahkemesi Kararlarında Terörizm. Ankara: 13. Hukuk İhtisas Semineri 
[5] Bilir H (2009) Terör,-Medya ve Devlet. İstanbul: IQ Kültür Sanat Yayıncılık

[6] Ergil D (1992) Uluslararası Terörizm. Ankara Üniversitesi SBF Dergisi Cilt:47 Sayı:3

[7] Fidan M (2006) Terör ve Medya, Terörün Görüntüleri, Görüntülerin Terörü. Konya: Çizgi Kitabevi

[8] Gezgin S (2006) Haber ve Terör. Terörün Görüntüleri, Görüntülerin Terörü. Konya: Çizgi Kitabevi

[9] Hollingsworth M, (2005) How To Get Into Television, Radio and New Media. London: Continium

[10] Kazan H (2016) Terör- Medya Illişkisi ve Medyada Terör Haberciliği. Güvenlik Stratejileri Yıl:12 Sayı:24

[11] Küçükcan, T (2010) Terörün Sosyolojisi: Toplumsal Kökenleri Anlama İmkânı Uluslar Arası İlişkiler, Cilt 6, Sayı 24, Ankara

[12] Manovich L (2002) The Language of New Media, Massachusetts. London: The MIT Press Cambridge

[13] Matusitz j (2012) Terrorism and Communication. Thousand Oaks ABD: Sage Pulitions

[14] Pazarbaşı B, Koç S (2009) 3 Ocak 2008'de Diyarbakır'da Yaşanan Bombalı Terör Eylemi ve Basın Söylemleri. Terör ve Haber Söylemi, İstanbul: Literatürk

[16] Pellerin C (2016) Communicating Terror: an Analysis of ISIS Communication Strategy. Islam\&Politics, Stephane Lacroix, Sciences Po

[16] Şişman B (2012) Sayısal Kültür, Toplum ve Medya: MSN Örneği. Gümüşhane Üniversitesi İletişim Fakültesi Elektronik Dergisi, S:3

[17] Weimann G (2015) Terrorism in Cyberspace The Nexxt Generation. New York Columbia University Press

http://www.tdk.gov.tr/index.php?option=com_gts\&arama=gts\&guid=TDK.GTS.59eddca65af64 4.13545616, E.T 20.10.2017

[19] http://www.medyatava.com/haber/mehves-evin-bazilari-utanma-nedir-bilmiyor_40042, E.T. 07.03.2017

[20] http://www.sde.org.tr/tr/authordetail/teror-ve-medya/1099, E.T. 03.01.17

[21] http://www.siyasaliletisim.org/dr-bahadr-kaleaas/prof-dr-murat-oezgen/456-fadeoezguerlueue-balamnda-medya-ve-teroer-olgusu.html, E.T. 03.01.2017

[22] http://www.sde.org.tr/tr/authordetail/teror-ve-medya/1099, E.T. 26.06.2017

[23] https://www.theatlantic.com/international/archive/2014/06/isis-iraq-twitter-social-mediastrategy/372856/ E.T. 23.07.2017

[24] http://www.bbc.com/turkce/haberler-dunya-40187203, E.T. 23.09.2017

[25] http://www.bbc.com/turkce/haberler-dunya-40187203, E.T. 20.10.2017 